\title{
Evaluation of Adherence, Hemagglutination, and Presence of Genes Codifying for Virulence Factors of Acinetobacter baumannii Causing U rinary Tract Infection
}

\author{
Graziela Braun/ ${ }^{+}$, Marilda Carlos Vidotto*
}

\author{
Universidade Estadual do Oeste do Paraná, Colegiado do Curso de Farmácia, Rua Universitária 2069, 85819-110 Cascavel, PR, \\ Brasil *Departamento de Microbiologia, Universidade Estadual de Londrina, Londrina, PR, Brasil
}

Acinetobacter baumannii is a strictly aerobic bacterium which causes severe infections, however its pathogenic characteristics are not well defined. Thirteen A. baumannii strains isolated from urine of hospitalized and nonhospitalized patients with different ages were investigated for the presence of virulence factors. The isolates belonged to biotypes 2, 6, and 9 and were sensitive to imipenem. The majority of them showed resistance to amikacin, ceftazidime, ceftriaxone, ciprofloxacin, gentamicin, norfloxacin, and trimethoprim-sulfamethoxazole. None of A. baumannii strains presented genes codifying for 17 different virulence factors previously described in uropathogenic Escherichia coli, when tested by polymerase chain reaction (PCR). Nine isolates agglutinated human group AB erythrocytes, in presence of mannose, but none of them agglutinated group O erythrocytes. Adherence to polystyrene was observed in 7 isolates, and this result did not correlate with that obtained in hemagglutination assay. All the isolates were able to grow in iron-limiting conditions, showing that A. baumannii produces some type of siderophore. However, the genes iutA and fyuA, from iron uptake system of E. coli and Yersinia sp., respectively, were not present in the isolates, suggesting the presence of a different type of siderophore. The fimbriae of A. baumannii strains that mediates the adherence are possibly mannose-resistant, eventhough the mechanism of adherence to human epithelial cells still remains to be elucidated.

Key words: Acinetobacter baumannii - adherence - hemagglutination - siderophore - virulence factors

Acinetobacter baumannii is a gram-negative coccobacillus, strictly aerobic, nonmotile, and usually commensal. During the last few decades it emerged as an important opportunistic pathogen due to characteristics that favor its persistence at the hospital environment. A. baumannii is resistant to the action of many antimicrobial drugs, spreads easily from patient to patient and survives desiccation, persisting in the environment for many days causing extended epidemic outbreaks (BergogneBérézin \& Towner 1996). Nineteen biotypes have been described within the species (Bouvet \& Grimont 1987, Bouvet et al. 1990), but only some of them are prevalent in certain geographical areas.

The more common sites of infection by A. baumannii are respiratory and urinary tracts, and wounds, and septicemia is a frequent event (Schreckenberger \& Graevenitz 1999). The potential risk factors for these infections are advanced age, immunodepression, surgery, presence of invasive devices, use of antimicrobial agents, and the increased length of stay in hospital and intensive care units (ICU) (Bergogne-Bérézin \& Towner 1996).

Although A. baumannii is considered to be relatively low-grade pathogen, some characteristics of this bacterium may enhance the virulence of the strains involved in

\footnotetext{
Financial support: Capes

${ }^{+}$Corresponding author. Fax: +55-45-220-3280. E-mail: grazibraun@yahoo.com.br

Received 16 April 2004

Accepted 5 November 2004
}

infections. Among the virulence factors (VF) it is included: the adhesion to human epithelial cells in the presence of fimbriae and/or capsular polysaccharide (Rosenberg et al. 1981, 1983); the polysaccharide capsule, that probably renders the surface of strains more hydrophilic (Kaplan et al. 1985); the high surface hydrophobicity of certain strains, that facilitates the adherence to prostheses and catheters (Boujaafar et al. 1990); ability to grow in ironchelated medium by secreting iron-regulated siderophores (Actis et al. 1993); and adhesion to rat bladder tissue what may be a factor contributing to the pathogenicity in the urinary tract or in other tissues (Sepulveda et al. 1998).

During the past decades, new VF have been described in Escherichia coli. Pathogenicity-associated islands (PAI) are blocks of VF genes that provide a mechanism to coordinate horizontal transfer of VF genes between lineages, and even between species, have emerged as characteristic of diverse pathogenic bacteria, including uropathogenic E. coli strains (Johnson \& Stell 2000). Recognized VF in uropathogenic $E$. coli include diverse adhesins, as P fimbriae (pap genes), S and F1C (sfa), Drantigen family ( $a f a / d r a)$, type 1 fimbriae $(\mathrm{fimH})$ (Le Bouguenec et al. 1992, Johnson \& Stell 2000) and curli fibers ( $c s g$ ) (Gophna et al. 2001); fibronectin receptor $(f b n)$ (Sarén et al. 1999); toxins, as cytotoxic necrotizing factor (cnf) (Blanco et al. 1990); siderophores, as yersiniabactin (fyuA) and aerobactin (iutA); invasins as IbeA; polysaccharide coatings as group II and III capsules (kpsMT); serum resistance (traT) (Montenegro et al. 1985) and colicin $\mathrm{V}$ production $(\mathrm{cvaC})$.

The purposes of this work were to evaluate the ability of $A$. baumannii strains isolated from urine to grow in 
iron-chelated medium; to detect the adherence to polystyrene, the presence of mannose-resistant hemaglutinins and genes codifying for VF previously described in uropathogenic E. coli.

\section{MATERIALS AND METHODS}

Bacterial isolates - Thirteen A. baumannii strains were isolated from urine of hospitalized and nonhospitalized patients in different wards of a university hospital in the city of Londrina, Paraná, Brazil, between January and April 2001. The strains were stored in glycerol tryptcasein soy broth (TSB) at $-20^{\circ} \mathrm{C}$.

A. baumannii ATCC 19606 was utilized as control. The strains E. coli FV35 (afa/dra), E. coli FVL2 (cnf1, papC and sfa/focDE), E. coli S5 (cnf2), E. coli C600 (csgA), E. coli LG1315 (cvaC), E. coli V27 (fim H, fyuA, iutA, kpsMT, papG II,III, and PAI), E. coli RS218 (ibeA, sfaS and traT), Staphylococcus aureus ATCC 25923 ( $f b n$ ) were utilized as positive controls for VF.

Biotyping and susceptibility to antimicrobial drugs - Bacteria were biotyped according to Bouvet and Grimont (1987), using M70 defined broth with the specific C sources: levulinate, citraconate, L-phenylalanine, phenylacetate, 4-hydroxybenzoate, and L-tartrate (Sigma Chemical Co, US). Filter-sterilized carbon sources were added at a final concentration of $0.1 \%$ (wt/vol). Growth of bacteria was recorded after 2 and 6 days at $37^{\circ} \mathrm{C}$.

Susceptibility to antimicrobial drugs was assessed by MicroScan Walk-Away (Dade Behring, West Sacramento, CA), utilizing panel Combo 1 to amikacin, ceftazidime, ceftriaxone, ciprofloxacin, gentamicin, imipenem, norfloxacin, tobramycin, and trimethoprim-sulfamethox-azole, according to the manufacturer's recommendations. Isolates showing an intermediate level of susceptibility were classified as resistant.

Growth under iron-limiting conditions - The isolates were grown on M9 minimal medium containing the iron chelator 2,2-dipyridyl (DIP) (Sigma) in concentrations of $50 \mu \mathrm{M}$ and $200 \mu \mathrm{M}$ and $2 \%$ agar (Echenique et al. 1992). The plates were incubated at $37^{\circ} \mathrm{C}$ for $18 \mathrm{~h}$. DIP was pre-

A

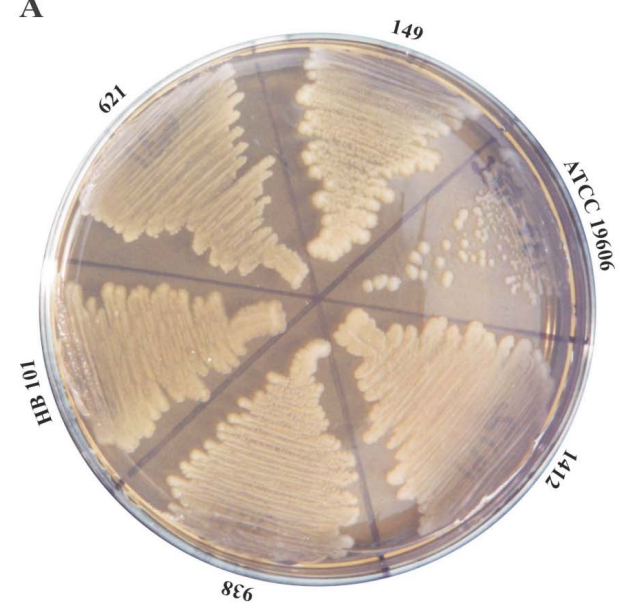

pared as a $20 \mathrm{mM}$ stock solution in distilled water and kept at $-20^{\circ} \mathrm{C}$.

Hemagglutination assay - Hemagglutinating activity was determined by micro-hemagglutination test using 96well round-bottom plates and fresh human group $\mathrm{O}$ and $\mathrm{AB}, \mathrm{Rh}$ positive erythrocytes. Bacteria were grown on Luria Bertani plates at $37^{\circ} \mathrm{C}$ for $24 \mathrm{~h}$, suspended and serially diluted in PBS, and the starting concentration was $10^{10} \mathrm{bacteria} / \mathrm{ml}$. A suspension of $1 \%$ erythrocytes containing 1\% D-mannose (Sigma) was added to each well and mixed. Wells containing only the suspension of erythrocytes were utilized as negative control. A small pellet of erythrocytes at the bottom after $1 \mathrm{~h}$ incubation at $4^{\circ} \mathrm{C}$ were considered negative, and those containing an even sheet of erythrocytes across the well were considered positive (Sepulveda et al. 1998).

Adherence to polystyrene - A simple replica method was used to study adherence to polystyrene (Rosenberg 1981). A polystyrene disk is pressed onto an agar plate containing bacterial isolates growth after incubation at $37^{\circ} \mathrm{C}$ for $24 \mathrm{~h}$. The replica formed is then extensively washed under tap running water and stained with gentian violet. Colonies of adherent bacteria remain bound to the polystyrene surface, whereas, the nonadherent ones are removed during the washing. E. coli strain HB101 was used as negative control.

$P C R$ - Bacterial DNA to be amplified was released from whole microorganisms by boiling (Le Bouguenec et al. 1992); the oligonucleotides used are shown in Table I. PCR was carried out in a total volume of $25 \mu 1$ containing $5 \mu 1$ of template DNA, $20 \mathrm{pmol}$ of each of the primers, the four deoxynucleoside triphosphates (each at $200 \mu \mathrm{M}$ ), PCR buffer with $2.5 \mathrm{mM}$ of $\mathrm{MgCl}_{2}$, and $1.5 \mathrm{U}$ of Taq DNA polymerase (Gibco). Amplifications were carried out as follows: a cycle of $95^{\circ} \mathrm{C}$ for $12 \mathrm{~min}, 25$ cycles of $94^{\circ} \mathrm{C}$ for $30 \mathrm{~s}$, annealing at $63^{\circ} \mathrm{C}$ for $30 \mathrm{~s}, 68^{\circ} \mathrm{C}$ for $3 \mathrm{~min}$, and a final extension at $72^{\circ} \mathrm{C}$ for $10 \mathrm{~min}$ in a Thermal Cycler (Gene Amp PCR System 9700/Perkin Elmer). Different temperatures of annealing of $60^{\circ} \mathrm{C}, 50^{\circ} \mathrm{C}$, and $40^{\circ} \mathrm{C}$ were only utilized with the primers Fbn, CsgA and Cnf2, respectively.

\section{B}

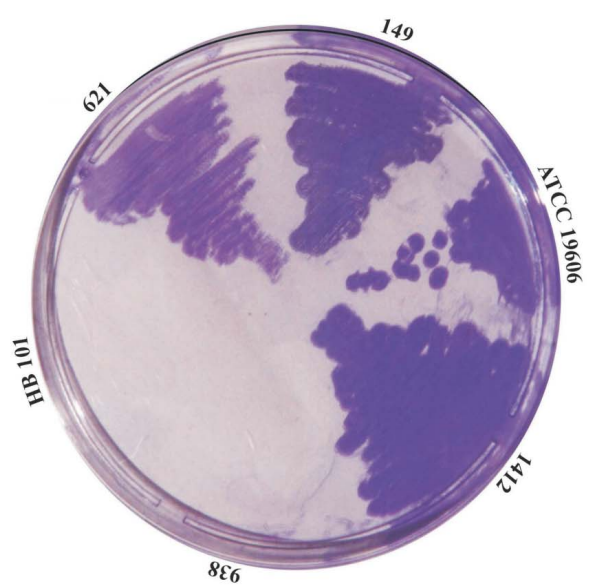

Adherence to polystyrene. A: nutrient agar plate containing Acinetobacter baumannii isolates; B: polystyrene replica stained with gentian violet. 621, 149, and 1412: adherent isolates; 938: nonadherent isolate; Eschirechia coli strain HB101: negative control; A. baumannii ATCC 19606: positive control. 
The amplified DNA was visualized in $1.5 \%$ agarose gels stained with ethidium bromide. The 100-bp ladder (Gibco) was used as standard for determining molecular mass of PCR products.

\section{RESULTS AND DISCUSSION}

Numerous outbreaks of nosocomial infections caused by multiresistant $A$. baumannii have been reported in various countries, including Brazil (Oliveira et al. 1993, Bergogne-Bérézin \& Towner 1996, Levin et al. 1996, Vaz et al. 1996). Important risk factors are involved in the urinary tract infections, which occur mostly in elderly debilitated patients confined to ICU, and with permanent urinary cath- eters. In this work the isolates were obtained from patients aging 18 to 88 years, and the 18 year-old patient was in use of permanent urinary catheter (Table II). Six strains were isolated from inpatients, being 2 from ICU and 4 from infirmaries; and 7 strains were isolated from outpatients being 3 from emergency and 4 from ambulatory.

The isolates belonged to biotypes $2(6 / 13), 6(6 / 13)$, and $9(1 / 13)$; they did not present association with the origin of isolation, and were uniform in their sensitivity to imipenem. Three isolates from nonhospitalized patients were sensitive to the majority of the tested drugs. The others, showed resistance to amikacin, ceftriaxone,

TABLE I

Primers to virulence factors utilized in polymerase chain reaction

\begin{tabular}{|c|c|c|c|c|c|}
\hline Gene & $\begin{array}{l}\text { Virulence } \\
\text { factor }\end{array}$ & $\begin{array}{l}\text { Name } \\
\text { of primer }\end{array}$ & Sequence (5'-3') & $\begin{array}{l}\text { Amplified } \\
\text { DNA (bp) }\end{array}$ & Reference \\
\hline$a f a / d r a B C$ & Dr fimbriae & $\begin{array}{l}\text { afa1 } \\
\text { afa2 }\end{array}$ & $\begin{array}{l}\text { GCTGGGCAGCAAACTGATAACTCTC } \\
\text { CATCAAGCTGTTTGTTCGTCCGCCG }\end{array}$ & 750 & Le Bouguenec et al. (1992) \\
\hline cnfl & $\begin{array}{l}\text { cytotoxic } \\
\text { necrotizing } \\
\text { factor }\end{array}$ & $\begin{array}{l}\operatorname{cnf} 1 \\
\operatorname{cnf} 2\end{array}$ & $\begin{array}{l}\text { AAGATGGAGTTTCCTATGCAGGAG } \\
\text { CATTCAGAGTCCTGCCCTCATTATT }\end{array}$ & 498 & Yamamoto et al. (1995) \\
\hline cnf 2 & $\begin{array}{l}\text { cytotoxic } \\
\text { necrotizing } \\
\text { factor }\end{array}$ & $\begin{array}{l}\operatorname{cnf} 2 a \\
\operatorname{cnf} 2 b\end{array}$ & $\begin{array}{l}\text { AATCTAATTAAAGAGAAC } \\
\text { CATGCTTTGTATATCTA }\end{array}$ & 543 & Blanco et al. (1996) \\
\hline $\operatorname{csg} A$ & curli fiber & $\begin{array}{l}\text { M464 } \\
\text { M465 R }\end{array}$ & $\begin{array}{l}\text { ACTCTGACTTGACTATTACC } \\
\text { AGATGCAGTCTGGTCAAC }\end{array}$ & 200 & \\
\hline$c v a C$ & $\operatorname{colicin} \mathrm{V}$ & $\begin{array}{l}\text { ColV-Cf } \\
\text { ColV-Cr }\end{array}$ & $\begin{array}{l}\text { CACACACAAACGGGAGCTGTT } \\
\text { CTTCCCGCAGCATAGTTCCAT }\end{array}$ & 680 & Johnson \& Stell (2000) \\
\hline$f b n$ & $\begin{array}{l}\text { fibronectin } \\
\text { receptor }\end{array}$ & $\begin{array}{l}\text { Fbn F1 } \\
\text { Fbn R1 }\end{array}$ & $\begin{array}{l}\text { GGTAATCAGTCATTCGAG } \\
\text { TGGCACACTGTCGAAGTC }\end{array}$ & $\begin{array}{c}207 \\
93\end{array}$ & \\
\hline $\operatorname{fim} H$ & $\begin{array}{l}\text { type } 1 \\
\text { fimbriae }\end{array}$ & $\begin{array}{l}\text { FimH f } \\
\text { FimH r }\end{array}$ & $\begin{array}{l}\text { TGCAGAACGGATAAGCCGTGG } \\
\text { GCAGTCACCTGCCCTCCGGTA }\end{array}$ & 508 & Johnson \& Stell (2000) \\
\hline fyuA & yersiniabactin & $\begin{array}{l}\text { FyuA f } \\
\text { FyuA r }\end{array}$ & $\begin{array}{l}\text { TGATTAACCCCGCGACGGGAA } \\
\text { CGCAGTAGGCACGATGTTGTA }\end{array}$ & 880 & $\begin{array}{l}\text { Johnson \& Stell (2000), } \\
\text { Schubert et al. (1998) }\end{array}$ \\
\hline$i b e A$ & invasin & $\begin{array}{l}\text { ibe10 } \\
\text { fibe10 } \mathrm{r}\end{array}$ & $\begin{array}{l}\text { AGGCAGGTGTGCGCCGCGTAC } \\
\text { TGGTGCTCCGGCAAACCATGC }\end{array}$ & 170 & $\begin{array}{l}\text { Huang et al. (1995), } \\
\text { Johnson \& Stell (2000) }\end{array}$ \\
\hline iutA & aerobactin & $\begin{array}{l}\text { AerJ f } \\
\text { AerJ r }\end{array}$ & $\begin{array}{l}\text { GGCTGGACATCATGGGAACTGG } \\
\text { CGTCGGGAACGGGTAGAATCG }\end{array}$ & 300 & Johnson \& Brown (1998) \\
\hline kpsMT II & capsule & $\begin{array}{l}\text { kpsII f } \\
\text { kpsII } r\end{array}$ & $\begin{array}{l}\text { GCGCATTTGCTGATACTGTTG } \\
\text { CATCCAGACGATAAGCATGAGCA }\end{array}$ & 272 & Johnson \& Stell (2000) \\
\hline PAI & $\begin{array}{l}\text { pathogenicity } \\
\text {-associated } \\
\text { island }\end{array}$ & $\begin{array}{l}\text { RPAi f } \\
\text { RPAi r }\end{array}$ & $\begin{array}{l}\text { GGACATCCTGTTACAGCGCGCA } \\
\text { TCGCCACCAATCACAGCCGAAC }\end{array}$ & 930 & Johnson \& Stell (2000) \\
\hline papC & P fimbriae & $\begin{array}{l}\text { pap } 1 \\
\text { pap2 }\end{array}$ & $\begin{array}{l}\text { GACGGCTGTACTGCAGGGTGTGGCG } \\
\text { ATATCCTTTCTGCAGGGATGCAATA }\end{array}$ & 328 & Le Bouguenec et al. (1992) \\
\hline PapG II, III & I P fimbriae & $\begin{array}{l}\text { pGf } \\
\text { pGr }\end{array}$ & $\begin{array}{l}\text { CTGTAATTACGGAAGTGATTTCTG } \\
\text { ACTATCCGGCTCCGGATAAACCAT }\end{array}$ & 1070 & Marklund et al. (1992) \\
\hline$s f a / f o c D E$ & $\mathrm{~S}$ fimbriae & $\begin{array}{l}\text { sfa1 } \\
\text { sfa2 }\end{array}$ & $\begin{array}{l}\text { CTCCGGAGAACTGGGTGCATCTTAC } \\
\text { CGGAGGAGTAATTACAAACCTGGCA }\end{array}$ & 410 & Le Bouguenec et al. (1992) \\
\hline$s f a S$ & S fimbriae & $\begin{array}{l}\text { SfaS f } \\
\text { SfaS r }\end{array}$ & $\begin{array}{l}\text { GTGGATACGACGATTACTGTG } \\
\text { CCGCCAGCATTCCCTGTATTC }\end{array}$ & 240 & Johnson \& Stell (2000) \\
\hline $\operatorname{traT}$ & serum resistance & $\begin{array}{l}\text { TraT f } \\
\text { TraT r }\end{array}$ & $\begin{array}{l}\text { GGTGTGGTGCGATGAGCACAG } \\
\text { CACGGTTCAGCCATCCCTGAG }\end{array}$ & 290 & Johnson \& Stell (2000) \\
\hline
\end{tabular}


ciprofloxacin, trimethoprim-sulfamethoxazole; the resistance to other antimicrobials varied among the isolates (Table II). Hospitalized patients, from ICU and infirmaries, presented resistance to most antimicrobial agents tested, while nonhospitalized patients, from ambulatory and emergency, showed variable drug resistance patterns (Table II). Since these patients had been previously hospitalized the high resistance rates observed in these isolates could be due to the selection of the strains in the hospital environment.

Little is known about the mechanisms of pathogenicity of A. baumannii. In this work, we tested A. baumannii strains, isolated from urine, for the presence of genes that codify for various VF by PCR, as described for uropathogenic $E$. coli. All the isolates were negative to the VF analyzed.

Adherence is related to adhesins filamentous (fimbrial structures) or non-filamentous (Hornick et al. 1991). Fimbrial structures and their participation in adhesive properties involving fibronectin were investigated by means of agglutination assays (Köljelg et al. 1996). Sepulveda et al. (1998) verified that adherence to bladder tissue is a natural attribute of strains belonging to different $A$. baumannii biotypes, a comparable trait found in a uropathogenic E. coli strain. Additionally, the presence of fimbrial structures in A. baumannii isolates was correlated with the capacity to agglutinate human group $\mathrm{O}$ erythrocytes, in presence of mannose or galactose.

Hemagglutination tests have been used for the in vitro assay of the expression of many mannose-resistant hemaglutinins, designed fimbriae type P, S, Dr, and F, frequently found in extra-intestinal $E$. coli. In this work, 9 of 13 A. baumannii isolates agglutinated human group AB erythrocytes, in presence of mannose, but none of the isolates agglutinated human group $\mathrm{O}$ erythrocytes. In contrast, Sepulveda et al. (1998) described that all $A$. baumannii strains agglutinated human group $\mathrm{O}$ erythrocytes in presence of mannose. Although the isolates here studied present mannose-resistant hemaglutinins, the genes pap, afa/dra and sfa codifying for the fimbriae P, Dr, and $\mathrm{S}$, respectively, were not detected by means of PCR with specific primers.

Rosenberg (1981) described a high correlation between affinity of bacteria to polystyrene and surface hydrophobicity. The existence of thin fimbriae in A. baumannii which are a major factor in adherence to polystyrene was de-

TABLE II

Characteristics of patients and Acinetobacter baumannii strains isolated from urine

\begin{tabular}{|c|c|c|c|c|c|c|c|c|}
\hline \multirow[b]{2}{*}{ Strain } & \multirow{2}{*}{$\begin{array}{c}\text { Date of } \\
\text { isolation } \\
\text { (mo/day/yr) }\end{array}$} & \multirow{2}{*}{$\begin{array}{l}\text { Age } \\
(\mathrm{yr})\end{array}$} & \multirow[b]{2}{*}{ Ward } & \multirow{2}{*}{$\begin{array}{l}\text { Resistance profile } \\
(\mathrm{MIC} \text { in } \mu \mathrm{g} / \mathrm{ml})\end{array}$} & \multirow{2}{*}{$\begin{array}{l}\text { Biotype } \\
\text { B \& G }\end{array}$} & \multirow{2}{*}{$\begin{array}{l}\text { Polystyrene } \\
\text { adherence }\end{array}$} & \multicolumn{2}{|c|}{ Hemagglutination } \\
\hline & & & & & & & $\mathrm{O}^{+}$ & $\mathrm{AB}^{+}$ \\
\hline 135 & $01 / 15 / 01$ & 25 & ICU & $\begin{array}{l}\mathrm{AM}(>32), \mathrm{CZ}(>16), \mathrm{CX}(>32), \\
\mathrm{CP}(>2), \mathrm{ST}(>2 / 38)\end{array}$ & 2 & - & - & + \\
\hline 149 & 01/03/01 & 25 & $\mathrm{Amb}$ & - & 6 & + & - & - \\
\hline 621 & 01/10/01 & 44 & Amb & $\begin{array}{l}\mathrm{AM}(>32), \mathrm{CZ}(>16), \mathrm{CX}(>32), \mathrm{CP}(>2), \\
\mathrm{GN}(>8), \mathrm{NF}(>8), \mathrm{ST}(>2 / 38)\end{array}$ & 2 & + & - & - \\
\hline 922 & $04 / 09 / 01$ & 32 & $\mathrm{ICU}$ & $\begin{array}{l}\mathrm{AM}(32), \mathrm{CZ}(16), \mathrm{CX}(>32), \mathrm{CP}(>2), \\
\mathrm{GN}(>8), \mathrm{TO}(>8), \mathrm{ST}(>2 / 38)\end{array}$ & 2 & - & - & + \\
\hline 931 & 01/10/01 & 41 & Inf & $\begin{array}{l}\mathrm{AM}(>32), \mathrm{CZ}(>16), \mathrm{CX}(>32), \\
\mathrm{CP}(>2), \mathrm{GN}(8), \mathrm{NF}(>8), \mathrm{ST}(>2 / 38)\end{array}$ & 6 & + & - & + \\
\hline 938 & $01 / 15 / 01$ & 88 & Eme & $\begin{array}{l}\mathrm{AM}(>32), \mathrm{CZ}(>16), \mathrm{CX}(>32), \mathrm{CP}(>2), \\
\mathrm{GN}(>8), \mathrm{NF}(>8), \mathrm{ST}(>2 / 38)\end{array}$ & 2 & - & - & + \\
\hline 1185 & 01/18/01 & 44 & Inf & $\begin{array}{l}\mathrm{AM}(>32), \mathrm{CX}(16), \mathrm{CP}(>2), \\
\mathrm{GN}(>8), \mathrm{NF}(>8), \mathrm{ST}(>2 / 38)\end{array}$ & 6 & + & - & + \\
\hline 1412 & $01 / 22 / 01$ & 41 & Eme & - & 6 & + & - & + \\
\hline 1711 & $01 / 26 / 01$ & 81 & Eme & $\begin{array}{l}\mathrm{AM}(>32), \mathrm{CZ}(>16), \mathrm{CX}(>32), \\
\mathrm{CP}(>2), \mathrm{GN}(8), \mathrm{NF}(>8), \mathrm{ST}(>2 / 38)\end{array}$ & 2 & - & - & + \\
\hline 6001 & 03/29/01 & 75 & $\operatorname{Inf}$ & $\begin{array}{l}\mathrm{AM}(>32), \mathrm{CZ}(>16), \mathrm{CX}(>32) \\
\mathrm{CP}(>2), \mathrm{GN}(8), \mathrm{NF}(>8), \mathrm{ST}(>2 / 38)\end{array}$ & 2 & - & - & - \\
\hline 6526 & 04/06/01 & 83 & $\mathrm{Amb}$ & NF (8) & 6 & + & - & - \\
\hline 6531 & 04/06/01 & 18 & $\mathrm{Amb}$ & $\begin{array}{l}\mathrm{AM}(>32), \mathrm{CZ}(16), \mathrm{CX}(>32), \mathrm{CP}(>2), \\
\mathrm{GN}(>8), \mathrm{NF}(>8), \mathrm{TO}(>8), \mathrm{ST}(>2 / 38)\end{array}$ & 9 & + & - & + \\
\hline 6808 & $04 / 11 / 01$ & 42 & Inf & $\begin{array}{l}\mathrm{AM}(>32), \mathrm{CX}(>32), \mathrm{CP}(>2), \mathrm{GN}(>8), \\
\mathrm{NF}(>8), \mathrm{TO}(>8), \mathrm{ST}(>2 / 38)\end{array}$ & 6 & - & - & + \\
\hline
\end{tabular}

ICU: intensive care unit; Amb: ambulatory; Inf: infirmary; Eme: emergency; MIC: minimal inhibitory concentration; AM: amikacin; CZ: ceftazidime; CX: ceftriaxone; CP: ciprofloxacin; GN: gentamicin; NF: norfloxacin; ST: trimethoprim/sulfamethoxazole; TO: tobramycin; B \& G: Bouvet \& Grimont (1987); -: negative; +: positive 
scribed by Rosenberg et al. (1982). The surface hydrophobicity of microorganisms appears to play an important role in their attachment to various polymers (Magnusson 1982), and is related to adherence of microorganism to the plastic surface, as catheters and prostheses. In our work, 7 of 13 isolates from urine adhered to polystyrene (Figure), but no association was found with hemagglutination assay.

Another VF described in A. baumannii is the production of siderophores by isolates growing under iron-limiting conditions. These bacteria are capable to express highaffinity iron uptake systems composed by siderophores, components capable to convert polymeric ferric oxy-hydroxides into soluble iron chelates, and iron-repressible outer membrane proteins (IROMPS) (Neilands 1995). Smith et al. (1990) detected the presence of iron chelator 2,3-dihidroxi-benzoic acid (DHBA) and IROMPS in the culture supernatant of Acinetobacter sp. Besides DHBA, A. baumannii strains present other siderophores type catechol (Echenique et al. 1992, Actis et al. 1993). The Fur protein of A. baumannii, which regulates the genes involved in iron uptake, was sequenced and indicated that it is 63\% identical to that of $E$. coli (Daniel et al. 1999).

Considering that, in our work, all A. baumannii strains were able to grow in M9 medium plates containing $50 \mu \mathrm{M}$ and $200 \mu \mathrm{M}$ DIP, we conclude that this bacterium produces siderophores. However, the genes iutA and fyuA from iron uptake system of E. coli and Yersinia sp., respectively, were not present in the studied isolates, suggesting the presence of a different type of siderophore.

In conclusion, $A$. baumannii strains here studied do not possess DNA sequences similar to the codifying for VF present in uropathogenic $E$. coli; and possibly the fimbriae of A. baumannii mediating the adherence are mannose-resistant, eventhough the mechanism of adherence of A. baumannii still remains to be elucidated.

\section{ACKNOWLEDGMENTS}

To Halha O Saridakis for her significant contributions, Carlos M Nozawa for critical reading of this manuscript, James $\mathrm{R}$ Johnson for providing control strains, and the Laboratory of Clinical Microbiology, University Hospital, Londrina, Paraná, Brazil, for kindly providing isolates.

\section{REFERENCES}

Actis LA, Tolmasky ME, Crosa LM, Crosa JH 1993. Effect of iron-limiting conditions on growth of clinical isolates of Acinetobacter baumannii. J Clin Microbiol 31: 2812-2815.

Bergogne-Bérézin E, Towner KJ 1996. Acinetobacter spp. as nosocomial pathogens: microbiological, clinical, and epidemiological features. Clin Microbiol Rev 9: 148-165.

Blanco J, Alonso MP, Gonzalez EA, Blanco M, Garabal JI 1990. Virulence factors of bacteraemic Escherichia coli with particular reference to production of cytotoxic necrotising factor (CNF) by P-fimbriate strains. J Med Microbiol 31: 175-183.

Blanco M, Blanco JE, Blanco J 1996. Polymerase chain reaction for detection of Escherichia coli strains producing cytotoxic necrotizing factor type 1 and 2 (CNF1 and CNF2). J Microbiol Meth 26: 95-101.

Boujaafar N, Freney J, Bouvet PJM, Jeddi M 1990. Cell surface hydrophobicity of 88 clinical strains of Acinetobacter baumannii. Res Microbiol 141: 477-482.
Bouvet PJM, Grimont PAD 1987. Identification and biotyping of clinical isolates of Acinetobacter. Ann Inst Pasteur Microbiol 138: 569-578.

Bouvet PJM, Jeanjean S, Vieu JF, Dijkshoorn L 1990. Species, biotype, and bacteriophage type determinations compared with cell envelope protein profiles for typing Acinetobacter strains. J Clin Microbiol 28: 170-176.

Daniel C, Haentjens S, Bissinger MC, Courcol RJ 1999. Characterization of the Acinetobacter baumannii Fur regulator: cloning and sequencing of the fur homolog gene. FEMS Microbiol Lett 170: 199-209.

Echenique JR, Arienti H, Tolmasky ME, Read RR, Staneloni RJ, Crosa JH, Actis LA 1992. Characterization of a highaffinity iron transport system in Acinetobacter baumannii. J Bacteriol 174: 7670-7679.

Gophna U, Barlev M, Seijffers R, Oelschlager TA, Hacker J, Ron EZ 2001. Curli fibers mediate internalization of Escherichia coli by eukariotic cells. Infect Immun 69: 26592665.

Hornick DB, Allen BL, Horn MA, Clegg S 1991. Fimbrial types among respiratory isolates belonging to the family Enterobacteriaceae. J Clin Microbiol 29: 1795-1800.

Huang SH, Wass C, Fu Q, Prasadarao NV, Stins M, Kim KS 1995. Escherichia coli invasion of brain microvascular endothelial cells in vitro and in vivo: molecular cloning and characterization of invasion gene ibe10. Infect Immun 63: 4470-4475.

Johnson JR, Brown JJ 1998. Colonization with and acquisition of uropathogenic Escherichia coli strains as revealed by polymerase chain reaction-based detection. J Infect Dis 177: 1120-1124.

Johnson JR, Stell AL 2000. Extended virulence genotypes of Escherichia coli strains from patients with urosepsis in relation to phylogenic and host compromise. J Infect Dis 181: 261-272.

Kaplan N, Rosenberg E, Jann B, Jann K 1985. Structural studies of the capsular polysaccharide of Acinetobacter calcoaceticus BD4. Eur J Biochem 152: 453-458.

Köljelg S, Vuopio-Varkila JV, Lyytikäinen O, Mikelsaar M, Wadström T 1996. Cell surface properties of Acinetobacter baumannii. APMIS 104: 659-666.

Le Bouguenec CL, Archambaud M, Labigne A 1992. A rapid and specific detection of the pap, afa and sfa adhesin-encoding operons in uropathogenic Escherichia coli strains by polymerase chain reaction. J Clin Microbiol 30: 11891193.

Levin ASS, Mendes CMF, Sinto SI, Sader HS, Scarpitta CRM, Rodrigues E, Sauaia N, Boulos M 1996. An outbreak of multiresistant Acinetobacter baumannii in a university hospital in São Paulo, Brazil. Infect Control Hosp Epidemiol 17: 366-368.

Magnusson KE 1982. Hydrophobic interaction: a mechanism of bacteria binding. Scand J Infect Dis 33: 32-36.

Marklund BI, Tennent JM, Garcia E 1992. Horizontal gene transfer of the Escherichia coli pap and prs pili operons as a mechanism for the development of tissue-specific adhesive properties. Mol Microbiol 6: 2225-2242.

Montenegro MA, Bitter-Suermann D, Timmis JK, Agüero ME, Cabello FC, Sanyal SC, Timmis KN 1985. traT gene sequences, serum resistance and pathogenicity-related factors in clinical isolates of Escherichia coli and other gramnegative bacteria. J Gen Microbiol 131: 1511-1521.

Neilands JB 1995. Siderophores: structure and function of microbial iron transport compounds. J Biol Chem 270: 2672326726.

Oliveira MG, Vaz TMI, Gonçalves CR, Irino K, Levy CE 1993. Acinetobacter species in clinical isolates and detection of a 
new biotype of Acinetobacter baumannii. Rev Microbiol 24: 215-221.

Rosenberg E, Kaplan N, Pines O, Rosenberg M, Gutnick D 1983. Capsular polysaccharides interfere with adherence of Acinetobacter calcoaceticus to hydrocarbon. FEMS Microbiol Lett 17: 157-160.

Rosenberg M 1981. Bacterial adherence to polystyrene: a replica method of screening for bacterial hydrophobicity. Appl Environ Microbiol 42: 375-377.

Rosenberg M, Bayer EA, Delarea J, Rosenberg E 1982. Role of thin fimbriae in adherence and growth of Acinetobacter calcoaceticus RAG-1 on hexadecane. Appl Environ Microbiol 44: 929-937.

Rosenberg M, Perry A, Bayer EA, Gutnick DL, Rosenberg E, Ofek I 1981. Adherence of Acinetobacter calcoaceticus RAG1 to human ephitelial cells and to hexadecane. Infect Immun 33: 29-33.

Sarén A, Virkola R, Hacker J, Korhonen TK 1999. The cellular form of human fibronectin as an adhesion target for the $\mathrm{S}$ fimbriae of meningitis-associated Escherichia coli. Infect Immun 67: 2671-2676.

Sepulveda M, Ruiz M, Bello H, Dominguez M, Martínez MA,
Pinto ME, Gonzalez G, Mella S, Zemelman R 1998. Adherence of Acinetobacter baumannii to rat bladder tissue. Microbios 95: 45-53.

Schreckenberger PC, Graevenitz A 1999. Nonfermentative gramnegative rods. In PR Murray, Manual of Clinical Microbiology, ASM, Washington, p. 539-543.

Schubert S, Rakin A, Karch H, Carniel E, Hessemann J 1998. Prevalence of the "high-pathogenicity island" of Yersinia species among Escherichia coli strains that are pathogenic to humans. Infect Immun 66: 480-485.

Smith AW, Freeman S, Minett WG, Lambert PA 1990. Characterisation of a siderophore from Acinetobacter calcoaceticus. FEMS Microbiol Lett 70: 29-32.

Vaz TMI, Gonçalvez CR, Ghilardi ACR, Araújo E, Boni RF, Neme SN, Medeiros MIC, Irino K 1996. Acinetobacter species in clinical specimens: biotypes and serotypes of Acinetobacter baumannii strains isolated in São Paulo, Brazil. Rev Microbiol 27: 116-121.

Yamamoto S, Terai A, Yuri K, Kurazono H, Takeda Y, Yoshida O 1995. Detection of urovirulence factors in Escherichia coli by multiplex polimerase chain reaction. FEMS Immunol Med Microbiol 12: 85-90. 